\title{
A dural tear and a bleeding heart
}

Manav V. Vyas, MBBS, MSc, FRCPC

Neurology ${ }^{\circledR}$ 2018;91:758-759. doi:10.1212/WNL.0000000000006359

"Thank you, I mean to say, thank you, again," said Garron as he stood up to follow me out of the examination room at his follow-up visit.

It was just 6 weeks since headaches that had kept him from work got the attention they deserved. Garron is from a small Caribbean island country and has been in Canada for just over 4 years. Like many others, he moved here as a migrant farm worker, giving up a stable municipal job because of his country's financial difficulties and the uncertainty it brought to his career and life. His initial years had been difficult. Farm work was physically challenging, and the pay was low. Yet, he stayed the course and endured it all. In his second year here, he met a fellow countrywoman who was a naturalized Canadian citizen. They were to get married, and she promised him to help him obtain a permanent immigration status here. A year later, he was still an illegal migrant, betrayed by his own people: the marriage never happened, and his savings were used up. How could he learn to trust anyone again?

Ever resilient, he moved to the city, left the treacherous work environment of the farm, and rebuilt himself by fixing and renovating homes. He had also found a new love. She was kind and gentle, and understood that although his experiences had been challenging, his heart was pure and his intentions were clear.

One day, approximately 3 months ago, he woke up with a pulsating headache that built up in a few hours and became severe. He had never had a headache in his life. Acetaminophen gave some relief, but the headaches recurred; they were milder first thing in the morning after he woke up and worsened over the day. He soon learned that only lying down would relieve them.

After a few weeks of pain medications that included opiates, and 2 normal head CTs in 2 different emergency departments (EDs), nothing had changed. One Saturday, he was in the neighborhood with his girlfriend visiting friends when the headache became unbearable, and on their friends' suggestion, they came to our ED. A head CT was performed overnight, and he was given the concoction of tramadol and metoclopramide for pain control. His headache improved when he lay flat on the stretcher in the hallway. His CT revealed small bilateral subdural collections and no other abnormalities.

I saw him the next morning at the start of my call at 8 AM still lying on a stretcher in the hallway. The overcrowding in the ED was routine for a Sunday morning, the aftermath of a regular Saturday night. I was certain he had not slept; no one could. I learned that he had been having severe positional headaches that were not accompanied by any other neurologic symptoms and were worsened when he had had to sit, stand, or walk for greater than few minutes. He had not been able to work for approximately 4 weeks. He had no focal neurologic deficits on neurologic examination, but within 5 minutes of sitting up, he was grimacing, his headaches had returned, and my meticulous neurologic assessment was leading only to significant distress. The diagnosis was clear.

I told him that he most likely had intracranial hypotension and that while the heavy lifting required by his work might have been the cause, in most cases, the cause was unknown. He was admitted, and MRIs of the brain and spine with contrast performed the next day confirmed the diagnosis. His brain MRI showed right greater than left convexity subdural hematoma with minimal shift and sulcal effacement; diffuse pachymeningeal enhancement; drooping and

\section{Correspondence}

Dr. Vyas

manav.vyas@

mail.utoronto.ca

\section{MORE ONLINE}

ค Audio

Listen to Dr. Vyas read this story.

NPub.org/k7qo6m 
crowding of posterior fossa structures, along with cerebellar tonsils just above foramen magnum; and patent venous sinuses. The spine MRI showed an anterior epidural CSF collection in the cervical area extending from $\mathrm{C} 2$ to the $\mathrm{T} 1$ nerve roots. The culprit tear was hard to locate, although it was felt to be in the high thoracic region. Days of bed rest, ample hydration, and increased caffeine intake made no difference. On his fifth hospital day, he received an epidural blood patch and was subsequently discharged home after a few days of monitoring.

He had been doing well. Headaches occurred only momentarily in the morning and were getting better overall. He was able to sit up and walk around. In fact, in the past week, he had gone to work and did some landscaping.

His life had changed in other ways, however. Because of his precarious immigration status, he was not covered for his hospital stay, unlike others with permanent immigration status in Canada. A bill for thousands of dollars had arrived from the hospital.

"I will pay these off. I want to. I will. I just need time. And I need to go back to work," he told me. "Do you think I will be able to go work again?" His plea was clear, his body language crying for the answer, his shoulders drooped, and the eyes slowly drifting away, staring at the floor.

"I don't think you should go to work to do heaving lifting, yet," I said. "You are still at risk of developing this condition again if you strain yourself. It can lead to more trouble, not just for your health but also financially. You cannot afford another admission."

He nodded; his expression suggested that he understood the new reality.

"I think you should go to work, but do things that don't require heaving lifting," I had added. "Also, start slowly, perhaps 1 day a week, and gradually increase the days you work. Make sure you get time off in between to lie down and rest. If you develop positional headaches again, lie down and give us a call."

"OK", he said, "But, getting work is hard now. My cellphone service stopped because I could not pay the bills. I cannot get contracting jobs anymore."

"Work will come," I had said. "It will happen. You just need to be careful and cautious."
He nodded. It was difficult to see a stoic hard-working factotum submit to his physician's advice. I told him that I would not be submitting a bill for this visit. He did not have to worry about paying me. He was a bit puzzled. It gave me time to connect the dots.

I realized that I had seen him sitting in the waiting room 3 hours before his appointment, but amidst the busy clinic, all I had done was to nod at him. When I had inquired, he told me that he came early because he got a ride. He did not have money to afford a cab or public transit. In fact, when asked, he had told me he had not had lunch because he had no money on him. I gave him a small amount for lunch. I also asked his permission to discuss his case with people I know who work with refugees and/or migrant workers, and he had agreed to talk to them. I also told him that I was going to speak to the patient accounts department to request leniency toward the bills for his recent hospitalization.

As we stood up to leave the room, he could only say thank you.

The next week, I followed up with my acquaintances, and we were able to get an immigration lawyer for him. The manager of patient accounts reported that they would do their best to help this man. I was surprised to learn that it was the first time a physician had reached out to discuss a patient's case or bills. I wonder if it represented a lack of interest or motivation on the part of my colleagues to learn about their patient's hardships, or the lack of time to delve into these issues.

In India, I had worked in municipal hospitals that catered to low-income families. I remembered countless occasions when I had paid to help patients with clear symptoms and examination features of tuberculosis get a chest $\mathrm{x}$-ray to make the diagnosis. Every morning, I would see family members line up outside the hospital superintendent's office with bills-papers that attempted to put a value to human life - in their hands, hoping to get a minute of the superintendent's time to plea for leniency. Likewise, during my work in Zimbabwe, patients would travel for days to come to a remote mission hospital to receive subsidized care. Labor wards would have young women admitted for low body weight and low iron stores. The major part of their treatment plan involved receiving proper meals twice a day. We often take pride in how far medicine has come along, and yet basic needs of proper nutrition and clean water become the most important treatment measures in so many instances. At the same time, disparities in health are not just a third world phenomenon. I had just witnessed one such instance in a developed nation that prides in providing universal health care. 


\title{
Neurology
}

\author{
A dural tear and a bleeding heart \\ Manav V. Vyas \\ Neurology 2018;91;758-759 \\ DOI 10.1212/WNL.0000000000006359
}

This information is current as of October 15, 2018

$\begin{array}{ll}\begin{array}{l}\text { Updated Information \& } \\ \text { Services }\end{array} & \begin{array}{l}\text { including high resolution figures, can be found at: } \\ \text { http://n.neurology.org/content/91/16/758.full }\end{array} \\ \text { Subspecialty Collections } & \begin{array}{l}\text { This article, along with others on similar topics, appears in the } \\ \text { following collection(s): } \\ \text { All Clinical Neurology } \\ \text { http://n.neurology.org/cgi/collection/all_clinical_neurology } \\ \text { All Headache } \\ \text { http://n.neurology.org/cgi/collection/all_headache }\end{array} \\ & \begin{array}{l}\text { Information about reproducing this article in parts (figures,tables) or in } \\ \text { its entirety can be found online at: } \\ \text { http://www.neurology.org/about/about_the_journal\#permissions } \\ \text { Permissions \& Licensing } \\ \text { Information about ordering reprints can be found online: } \\ \text { http://n.neurology.org/subscribers/advertise }\end{array}\end{array}$

Neurology ${ }^{\circledR}$ is the official journal of the American Academy of Neurology. Published continuously since 1951, it is now a weekly with 48 issues per year. Copyright @ 2018 American Academy of Neurology. All rights reserved. Print ISSN: 0028-3878. Online ISSN: 1526-632X.

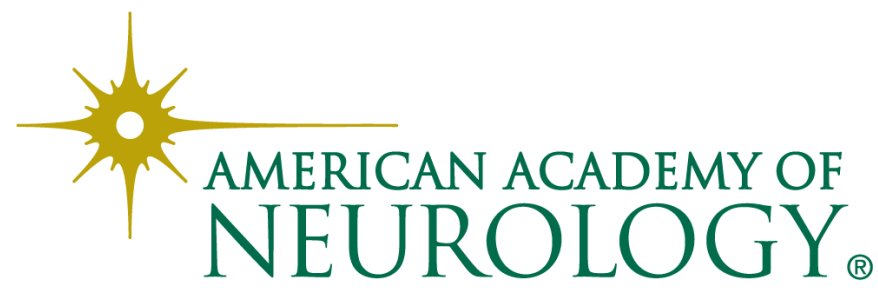

